\title{
COMPARISON OF EFFICACY OF MISOPROSTOL 4 HOURLY WITH MISOPROSTOL 6 HOURLY FOR MEDICALTERMINATION OF PREGNANCY IN SECOND TRIMESTER.
}

\footnotetext{
1. MBBS, FCPS, MCPS Assistant Professor Department of G\&O QAMC/BVH, Bahawalpur.

2. MBBS, FCPS

Women Medical Officer Department of G\&O Civil Hospital, Bahawalpur.

3. MBBS, FCPS

Assistant Professor Department of G\&O

Civil Hospital, Baawalpur.
}

Correspondence Address:

Dr. Shamas un Nisa

House No. 41D, Block Z,

Alfareed Mother Child Care Center,

Model Town C, Near Commercial

Market,

Bahawalpur

drshamaamin73@gmail.com

Article received on:

04/02/2019

Accepted for publication:

$15 / 10 / 2019$

\begin{abstract}
Shamas un Nisa', Farzana Razaq ${ }^{2}$, Sadaf un $\mathrm{Nisa}^{3}$
ABSTRACT: Termination of Pregnancy (TOP), in our country is carried out only when considerable danger to a fetus due to congenital abnormalities, intrauterine fetal loss or when maternal life is under threat. The principle concerns in providing second trimester termination include safety, efficacy, simplicity, low-cost, and fast acting with minimal side effects. Objectives: To compare the efficacy in term of complete abortion within 48 hours between protocol-I (200 $\mu \mathrm{g}$ misoprostol 4 hourly) versus protocol-II (200 $\mu \mathrm{g}$ misoprostol 6 hourly) for second trimester (14-24 weeks) medical termination of pregnancy. Study Design: Randomized controlled trial. Settings: Gynecology \& obstetrics unit-II, Bahawal Victoria Hospital (BVH) Bahawalpur. Period: From $1^{\text {st }}$ July 2017 to $30^{\text {th }}$ June 2018. Material \& Method: A total of 182 patients meeting the inclusion criteria were included in study. Ninety one patients were included in group-A and 91 patients were included in group-B. Women allocated to group-A was given misoprostol $200 \mu \mathrm{g}$ every 4 hour. Similar drug and dose were administered to women of group-B intra-vaginally, 6 hourly. Patients in both groups were monitored up to 48. If abortion occurred within 48 hours of induction, it was labeled as effective abortion otherwise it was regarded as failed abortion. Results: The mean age in group-A was 26.71 years 25.49 years in Group-B. In group-A, 89 (97.8\%) patients showed efficacy (abortion within 48 hours) and in group-B, 74 (81.32\%) patients showed efficacy to misoprostol. Conclusion: The regimen of using $200 \mu \mathrm{g}$ of vaginal misoprostol 4 hourly is more efficacious and quick for $2^{\text {nd }}$ trimester TOP with fewer side effects when compared to $200 \mu \mathrm{g}$ of vaginal misoprostol 6 hourly.
\end{abstract}

Key words: $\quad$ Abortion, Efficacy, Medical Termination of Pregnancy, Misoprostol, Second Trimester

Article Citation: Shamas un Nisa, Razza F, Sadaf un Nisa. Comparison of efficacy of Misoprostol 4 hourly with Misoprostol 6 hourly for Medical termination of pregnancy in second trimester. Professional Med J 2020; 27(1):46-51. DOI: 10.29309/TPMJ/2020.27.1.3169

\section{INTRODUCTION}

Globally, more than half of the pregnancies are not willingly achieved while around $20 \%$ end up being abortions. Termination of pregnancy (TOP) is quite common around the world. ${ }^{1}$ Termination of Pregnancy (TOP), in our country is carried out only when considerable danger to a fetus due to congenital abnormalities, intrauterine fetal loss or when maternal life is under threat. ${ }^{2}$

Majority of TOPs take place within 13 weeks and $5-15 \%$ in the $2^{\text {nd }}$ trimester. Usually, fetal reasons are revealed a bit late, TOP in the $2^{\text {nd }}$ trimester is a topic of interest. Prostaglandins are usually used for TOP whereas some other options are available for $2^{\text {nd }}$ trimester TOP. Heart failure is linked to intra-amniotic hypertonic saline infusion along with hearth failure and septic shock. Infections and uterine perforation are risked with evacuation and curettage. Cervical changes and uterine contractions are caused by misoprostol being a synthetic prostaglandin E1 analogue. , $^{3,4}$

Prostaglandins have changed the traditional management approach for TOP in $2^{\text {nd }}$ trimester. Before the availability of misoprostol, other prostaglandins such as prostaglandin E2 and prostaglandin F2 alpha (PGF2a) were mostly used for the termination of second trimester pregnancies. These agents are efficacious but expensive, require refrigeration and needed higher doses, and present higher numbers with fever, nausea, vomiting and diarrhea. .,6 $^{5}$ 
Many studies have documented results of misoprostol for $2^{\text {nd }}$ trimester TOP since early 1990s. Misoprostol is inexpensive, no special storage for temperature required and has few systemic effects. ${ }^{7}$ In these days of financial constraints, misoprostol is an economical and effective abortifacient drug for second trimester pregnancy termination. ${ }^{8,9}$ Out aim was to compare the efficacy in term of complete abortion within 48 hours between protocol-I (200 $\mu \mathrm{g}$ misoprostol 4 hourly) versus protocol-Il (200 $\mu \mathrm{g}$ misoprostol 6 hourly) for second trimester (14-24 weeks) medical TOP.

\section{MATERIAL AND METHODS}

This randomized controlled study was done gynecology \& obstetrics unit-I of BVH Bahawalpur, from $1^{\text {st }}$ July 2017 to $30^{\text {th }}$ June 2018 , using non probability consecutive sampling technique.

Sample size was calculated by taking level of confidence $(a)=5 \%$, power of study $(1-\beta)=$ $80 \%$, anticipated population proportion $\mathrm{P}-\mathrm{I}=$ $90.6 \%{ }^{10,11}$, anticipated population proportion P-II $=75 \%{ }^{9}$, and sample size turned out 182 patients. Ninety one patients (group-A) were given $200 \mu \mathrm{g}$ misoprostol 4 hourly and 91 patients (group-B) were given $200 \mu \mathrm{g}$ misoprostol 6 hourly.

All those women were included who had age between 16-40 years, presented with ultrasonic conformation of fetal death during mid-trimester (i.e. from 14-24 weeks), missed abortion or with sever congenital malformation (e.g. anencephalic, gross hydrocephalus with meningocele etc) not compatible with life, with singleton pregnancy and all were up to para-3. Women with gestation $<14$ weeks and >24 weeks, having history of previous uterine surgery (scarred uterus), with multiple pregnancies (twins and high multiples), or para-4 or more were excluded from the study.

The study was approved from hospital ethical committee. The procedure was explained to each case and written permission for TOP was acquired. Group-A had misoprostol $200 \mu \mathrm{g}$ in posterior vaginal fornix every 4 hour (maximum 6 doses in 24 hours). Group-B had same drug \& dose same way, 6 hourly (maximum of 4 doses in 24 hours).
Patients in both groups were monitored up to 48 hours after the start of induction with misoprostol. If abortion (expulsion of both fetus and placenta) occurred within 48 hours of induction, it was labeled as effective abortion otherwise it was regarded as failed abortion.

SPSS version-20 was used for data analysis. Efficacy was labeled in terms of abortion (expulsion of both fetus and placenta of 14-24 weeks) within 48 hours after start of induction, it was termed as effective if occurred within 48 hours otherwise it was labeled as failed. Efficacy of both groups was compared. Effect modifiers were controlled by stratification of data in term of age, and gestational age. Chi square test was applied to see the effect of these on outcome variables.

\section{RESULTS}

The mean age of patients in group-A was 26.71 years with standard deviation of 5.2 years. The minimum age of patients in Group-A was 17 years, maximum age of patients was 36 years. The mean age in group-B was 25.49 years with standard deviation of 5.1 years. The minimum age of patients was 17 years, maximum age 36 years. Amongst all patients, 73 patients were in 16-24 years of age group, 89 patients were in 2532 years of age group and 20 patients were in 33-40 years.

In group-A, 33 patients of 16-24 years of age group showed efficacy (abortion within 48 hours), 43 patients in 25-32 years of age group showed efficacy (abortion within 48 hours) while 2 patients showed no efficacy (abortion within 48 hours) and 13 patients in 33-40 years of age group showed efficacy (abortion within 48 hours) with insignificant $p$ value of 0.352 .

In group-B, 33 patients of 16-24 years of age group showed efficacy (abortion within 48 hours) while 7 patients showed no efficacy (abortion within 48 hours), 36 patients in 25-32 years of age group showed efficacy (abortion within 48 hours) while 8 patients showed no efficacy (abortion within 48 hours) and 5 patients in 33-40 years of age group showed efficacy (abortion within 48 hours) while 
2 patients showed no efficacy (abortion within 48 hours) with insignificant $p$ value of 0.781 .

In group-A 89 (97.8\%) patients showed efficacy (abortion within 48 hours) to misoprostol while $2(2.2 \%)$ showed no efficacy to misoprostol. In group-B, $74(81.32 \%)$ patients showed efficacy (abortion within 48 hours) to misoprostol while 17 (18.68\%) showed no efficacy to misoprostol.

In group- $A, 44$ patients were primigravida while 47 multigravida, and in group-B, 43 patients were in primigravida while 48 in multigravida with insignificant $p$ value of 0.882 .

In group-A, 44 patients of primigravida showed efficacy (abortion within 48 hours) and 45 patients of multigravida showed efficacy (abortion within 48 hours) while 2 patients showed no efficacy (abortion within 48 hours) with insignificant $p$ value of 0.166 .

In group-B, 36 patients of primigravida showed efficacy (abortion within 48 hours) while 7 patients showed no efficacy (abortion within 48 hours) and 38 patients of multigravida showed efficacy (abortion within 48 hours) while 10 patients showed no efficacy (abortion within 48 hours) with insignificant $p$ value of 0.578 .

\begin{tabular}{|c|c|c|c|c|}
\hline \multirow[t]{2}{*}{$\begin{array}{l}\text { Age Group } \\
\text { of Patients }\end{array}$} & \multicolumn{2}{|c|}{$\begin{array}{c}\text { Efficacy (Abortion } \\
\text { within } 48 \text { hours) } \\
\text { in group-A }\end{array}$} & \multirow[t]{2}{*}{ Total } & \multirow[t]{2}{*}{ P-Value } \\
\hline & Yes & No & & \\
\hline $\begin{array}{l}16-24 \text { years } \\
\text { of age group }\end{array}$ & $\begin{array}{c}33 \\
100.0 \%\end{array}$ & $\begin{array}{c}0 \\
0 \%\end{array}$ & $\begin{array}{c}33 \\
100.0 \%\end{array}$ & \multirow{4}{*}{0.352} \\
\hline $\begin{array}{l}25-32 \text { years } \\
\text { of age group }\end{array}$ & $\begin{array}{c}43 \\
95.6 \%\end{array}$ & $\begin{array}{c}2 \\
4.4 \%\end{array}$ & $\begin{array}{c}45 \\
100.0 \%\end{array}$ & \\
\hline $\begin{array}{l}33-40 \text { years } \\
\text { of age group }\end{array}$ & $\begin{array}{c}13 \\
100.0 \%\end{array}$ & $\begin{array}{c}0 \\
.0 \%\end{array}$ & $\begin{array}{c}13 \\
100.0 \%\end{array}$ & \\
\hline Total & $\begin{array}{c}89 \\
97.8 \%\end{array}$ & $\begin{array}{c}2 \\
2.2 \%\end{array}$ & $\begin{array}{c}91 \\
100.0 \%\end{array}$ & \\
\hline $\begin{array}{l}\text { Table-I. C } \\
48 \text { hour }\end{array}$ & $\begin{array}{l}\text { iparison } \\
\text { in differe } \\
\text { (misopr }\end{array}$ & $\begin{array}{l}\text { efficac } \\
\text { age grc } \\
\text { tol } 4 \text { ho }\end{array}$ & $\begin{array}{l}\text { (abortion } \\
\text { ips in gro } \\
\text { ly) }\end{array}$ & $\begin{array}{l}\text { vithin } \\
\text { p-A }\end{array}$ \\
\hline
\end{tabular}

\begin{tabular}{|c|c|c|c|c|}
\hline \multirow[t]{2}{*}{$\begin{array}{l}\text { Age Group } \\
\text { of Patients }\end{array}$} & \multicolumn{2}{|c|}{$\begin{array}{c}\text { Efficacy } \\
\text { (Abortion within } \\
48 \text { hours) in } \\
\text { group-B }\end{array}$} & \multirow[t]{2}{*}{ Total } & \multirow[t]{2}{*}{ P-Value } \\
\hline & Yes & No & & \\
\hline $\begin{array}{l}16-24 \text { years } \\
\text { of age group }\end{array}$ & $\begin{array}{c}33 \\
82.5 \%\end{array}$ & $\begin{array}{c}7 \\
17.5 \%\end{array}$ & $\begin{array}{c}40 \\
100.0 \%\end{array}$ & \multirow{4}{*}{0.781} \\
\hline $\begin{array}{l}25-32 \text { years } \\
\text { of age group }\end{array}$ & $\begin{array}{c}36 \\
81.8 \%\end{array}$ & $\begin{array}{c}8 \\
18.2 \%\end{array}$ & $\begin{array}{c}44 \\
100.0 \%\end{array}$ & \\
\hline $\begin{array}{l}33-40 \text { years } \\
\text { of age group }\end{array}$ & $\begin{array}{c}5 \\
71.4 \%\end{array}$ & $\begin{array}{c}2 \\
28.6 \%\end{array}$ & $\begin{array}{c}7 \\
100.0 \%\end{array}$ & \\
\hline Total & $\begin{array}{c}74 \\
81.3 \%\end{array}$ & $\begin{array}{c}17 \\
18.7 \%\end{array}$ & $\begin{array}{c}91 \\
100.0 \%\end{array}$ & \\
\hline \multicolumn{5}{|c|}{$\begin{array}{l}\text { Table-II. Comparison of efficacy (abortion within } \\
48 \text { hours) in different age groups in group-B } \\
\text { (misoprostol } 6 \text { hourly). }\end{array}$} \\
\hline \multirow[t]{2}{*}{$\begin{array}{l}\text { Group of } \\
\text { Patients }\end{array}$} & \multicolumn{2}{|c|}{$\begin{array}{l}\text { Efficacy } \\
\text { (Abortion within } \\
48 \text { hours) }\end{array}$} & \multirow[t]{2}{*}{ Total } & \multirow[t]{2}{*}{ P-Value } \\
\hline & Yes & No & & \\
\hline $\begin{array}{l}\text { Group-A } \\
\text { (misoprostol } \\
4 \text { hourly) }\end{array}$ & $\begin{array}{c}89 \\
97.8 \%\end{array}$ & $\begin{array}{c}2 \\
2.2 \%\end{array}$ & $\begin{array}{c}91 \\
100.0 \%\end{array}$ & \multirow{3}{*}{$<0.001$} \\
\hline $\begin{array}{l}\text { Group-B } \\
\text { (misoprostol } \\
6 \text { hourly) }\end{array}$ & $\begin{array}{c}74 \\
81.3 \%\end{array}$ & $\begin{array}{c}17 \\
18.7 \%\end{array}$ & $\begin{array}{c}91 \\
100.0 \%\end{array}$ & \\
\hline Total & $\begin{array}{c}163 \\
89.6 \%\end{array}$ & $\begin{array}{c}19 \\
10.4 \%\end{array}$ & $\begin{array}{c}182 \\
100.0 \%\end{array}$ & \\
\hline
\end{tabular}

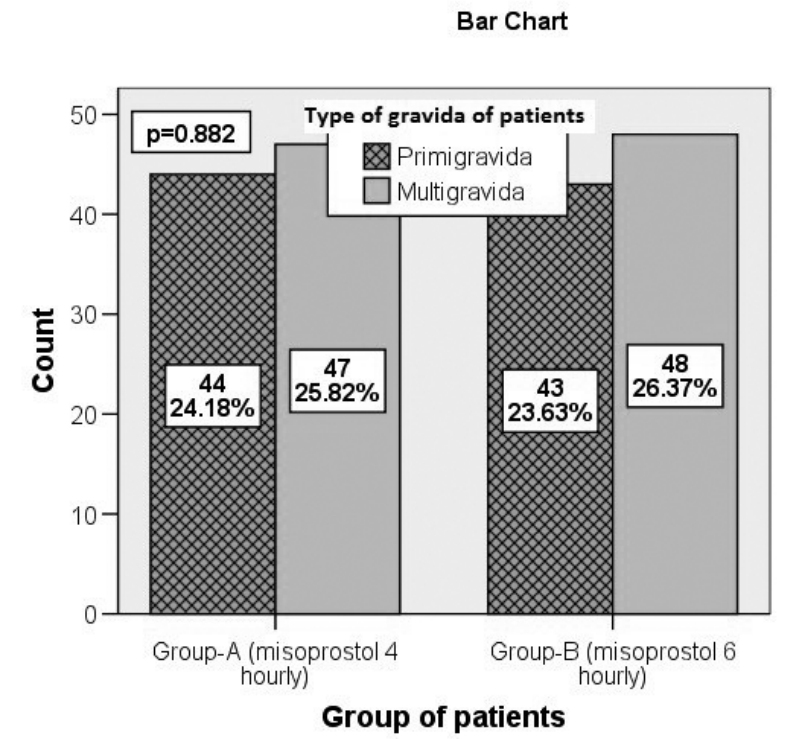

Figure-1. Frequency of primigravida and multigravida in patients of different groups 


\begin{tabular}{|c|c|c|c|c|}
\hline \multirow[t]{2}{*}{$\begin{array}{l}\text { Gravida of } \\
\text { Patients }\end{array}$} & \multicolumn{2}{|c|}{$\begin{array}{l}\text { Efficacy (Abortion } \\
\text { within } 48 \text { hours) } \\
\text { in group-A }\end{array}$} & \multirow[t]{2}{*}{ Total } & \multirow[t]{2}{*}{ P-Value } \\
\hline & Yes & No & & \\
\hline Primigravida & $\begin{array}{c}44 \\
100.0 \%\end{array}$ & $\begin{array}{c}0 \\
.0 \%\end{array}$ & $\begin{array}{c}44 \\
100.0 \%\end{array}$ & \multirow{3}{*}{0.166} \\
\hline Multigravida & $\begin{array}{c}45 \\
95.7 \%\end{array}$ & $\begin{array}{c}2 \\
4.3 \%\end{array}$ & $\begin{array}{c}47 \\
100.0 \%\end{array}$ & \\
\hline Total & $\begin{array}{c}89 \\
97.8 \%\end{array}$ & $\begin{array}{c}2 \\
2.2 \%\end{array}$ & $\begin{array}{c}91 \\
100.0 \%\end{array}$ & \\
\hline
\end{tabular}

Table-IV. Comparison of efficacy (abortion within 48 hours) in patients of primigravida and multigravida in group-A (misoprostol 4 hourly)

\begin{tabular}{|c|c|c|c|c|}
\hline \multirow[t]{2}{*}{$\begin{array}{l}\text { Gravida of } \\
\text { Patients }\end{array}$} & \multicolumn{2}{|c|}{$\begin{array}{l}\text { Efficacy (Abortion } \\
\text { within } 48 \text { hours) } \\
\text { in group-B }\end{array}$} & \multirow[t]{2}{*}{ Total } & \multirow[t]{2}{*}{ P-Value } \\
\hline & Yes & No & & \\
\hline Primigravida & $\begin{array}{c}36 \\
83.7 \%\end{array}$ & $\begin{array}{c}7 \\
16.3 \%\end{array}$ & $\begin{array}{c}43 \\
100.0 \%\end{array}$ & \multirow{3}{*}{0.578} \\
\hline Multigravida & $\begin{array}{c}38 \\
79.2 \%\end{array}$ & $\begin{array}{c}10 \\
20.8 \%\end{array}$ & $\begin{array}{c}48 \\
100.0 \%\end{array}$ & \\
\hline Total & $\begin{array}{c}74 \\
81.3 \%\end{array}$ & $\begin{array}{c}17 \\
18.7 \%\end{array}$ & $\begin{array}{c}91 \\
100.0 \%\end{array}$ & \\
\hline
\end{tabular}

\section{DISCUSSION}

We found misoprostol effective and safe. In 1989, Leihair et al ${ }^{12}$ initially noted the response of transvaginal misoprostol in the $2^{\text {nd }}$ trimester. A bit later, effects of misoprostol in comparison to other PGs were then documented as effective by Baird et al. ${ }^{13}$

In our study, the efficacy in group-A was $97.8 \%$ and efficacy in group-B was $81.32 \%$. This efficacy was comparable to other studies. A study conducted by Herabutya $Y$ et $\mathrm{al}^{14}$ found $74 \%$ \& $67 \%$ abortion rates respectively in similar groups within twenty four hours while 94\% \& 92\% in forty eight hours. In Group-I, 53\% women had fever in comparison to $31 \%$ in group-II $(P<0.001)$. In a study conducted by Akhtar $S$ et $\mathrm{al}^{15}$ found a shorter median induction to abortion time as 14.4 hours with vaginal misoprostol 400ug 4 hourly vs. 18.2 hours when compared to similar dose at 6 hourly $(p<0.001)$. Although similar study noted significantly more women with fever in Group-1.
Both groups witnessed decrease in symptoms associated to pregnancy.

Ruangchainikhom W et $\mathrm{al}^{16}$ noted that $38 \%$ \& 57\% abortion in Group-I and Group-II respectively $(p<0.05)$. Bhattacharyya and colleagues ${ }^{17}$ got no major disparity in time interval at 24 \& 48 hours when they compared both regimens. Chaudhuri $S$ et $\mathrm{al}^{18}$ compared women who were given vaginal misoprostol $400 \mathrm{ug}$, six hourly (maximum of four doses) with vaginal misoprostol 400 ug every 12 hourly (maximum of four doses). Statistically shorter interval difference was found both the groups (12.59 hours vs 16.41 hours respectively). More (57\%) attained abortion in 12 hours in Group-I in comparison to only $26 \%$ in Group B. Similar findings were noted by Wong KS and coworkers but with 3 hourly vs 6 hourly regimens. ${ }^{19}$

Niroomanesh $\mathrm{S}$ et $\mathrm{al}^{20}$ noted more than $80 \%$ eviction of conception products while no real difference was found in terms of hospital stay or side effects. Some other researchers also found misoprostol a good option for expulsion of conception products with less side effects. ${ }^{21-23}$

We used a lower dose of misoprostol as compared to many previous studies and noted it to be effective. As the side effects of misoprostol are related to dose, lowest effective dose is advised. Comparison of vaginal misoprostol dosage regarding induction of labor at term has not been extensively evaluated and more studies are required.

\section{CONCLUSION}

The regimen of using $200 \mu \mathrm{g}$ of vaginal misoprostol 4 hourly is more efficacious and quick for $2^{\text {nd }}$ trimester TOP with fewer side effects when compared to $200 \mu \mathrm{g}$ of vaginal misoprostol 6 hourly.

\section{Copyright@ 15 Oct, 2019.}

\section{REFERENCES}

1. Dawson AJ, Nicolls R, Bateson D, Doab A, Estoesta $\mathrm{J}$, Brassil A, et al. Medical termination of pregnancy in general practice in Australia: A descriptiveinterpretive qualitative study. Reprod Health. 2017; 14: 39. 
2. Mahjabeen NPK, Khawaja NP, Rehman R. Comparison of oral versus vaginal misoprostol for mid-trimester pregnancy termination. J Coll Physicians Surg Pak. 2009; 19(6):359-62.

3. Chaudhuri S, Banerjee PK, Mundle M, Mitra SN. A comparison of two regimens of misoprostol for second trimester medical termination of pregnancy: A randomized trial. Trop Doct. 2010; 40:144-8.

4. Lin CJ, Chien SC, Chen CP. The use of misoprostol in termination of second-trimester pregnancy. Taiwan $\mathrm{J}$ Obstet Gynecol. 2011; 50:275-82.

5. Elati A, Weeks AD. The use of misoprostol in obstetrics and gynaecology. Br J Obstet Gynecol. 2009; 116:619.

6. Imran F, Anser A, Danish N, Fatima N. Misoprostol for the purpose of mid-trimester termination of pregnancy: A comparative study with prostaglandin f2 alpha. J Ayub Med Coll Abbottabad. 2010; 22(4):8791.

7. Cabrera Y, Fernandez-Guisasola J, Lobo P, Gamir S, Alvarez J. Comparison of sublingual versus vaginal misoprostol for second-trimester pregnancy termination: A meta-analysis. Aust N Z J Obstet Gynaecol. 2011; 51:158-65.

8. Chai J, Tang OS, Hong QQ, Chen QF, Cheng LN, Ng E. A randomized trial to compare two dosing intervals of misoprostol following mifepristone administration in second trimester medical abortion. Hum Reprod. 2009; 24:320-4.

9. Sobia N, Nadra S. Role of Misoprostol for therapeutic termination of pregnancy from 10-28 weeks of gestation. J Pak Med Assoc. 2007; 57:129-32.

10. Karim SMW, Trussell RR, Patel RC, Hillier R. Response of pregnant Human Uterus to prostaglandin F2ainduction of labour. BMJ. 1968; 4:621-23.

11. Kwon JS, Mackenzie VP, Davies GAL. A comparison of oral and vaginal misoprostol for induction of labour at term; A randomized trial. $\mathrm{Br} \mathrm{J}$ Obstet Gynecol. 2001; 108:1-4.

12. Lehair J, Lemarie P, Helleringer M, Manini P. Expulsion of arrested pregnancy product in the second trimester using a prostaglandin E1 analog administered intravaginally. Apropos of 12 cases. Rev Fr Gynecol Obstect. 1989; 84:19-23.
13. Baird DT, Norman JE, Thong KJ, Glasier AF. Misoprostol, mifepristone, and abortion. Lancet. 1992; 339:13.

14. Herabutya $Y$, Chanrachakul B, Punyavachira P. A randomized controlled trial of 6 and 12 hourly administration of vaginal misoprostol for second trimester pregnancy termination. BJOG. 2005; 112(9):1297-301.

15. Akhtar S, Fatima Y. A comparison of two protocols of intravaginal misoprostol for second trimestrer medical termination of pregnancy. Pak Armed Forces Med J. 2011; (1):20-3.

16. Ruangchainikhom W, Phongphissanou E, Bhekasuta J, Sarapak S. Effectiveness of $\mathbf{4 0 0}$ or $\mathbf{6 0 0}$ micrograms of vaginal misoprostol for terminations of early pregnancies. J Med Assoc Thai. 2006; 89(7):928-33.

17. Bhattacharyya SK, Mukherji J, Kamilya GS, Ray S, Hazra A. Two regimens of vaginal misoprostol in second trimester termination of pregnancy: A prospective randomized trial. Acta Obstet Gynecol Scand. 2006; 85(12):1458-62.

18. Chaudhuri S, Banerjee PK, Mundle M, Mitra SN. A comparison of two regimens of misoprostol for second trimester medical termination of pregnancy: A randomized trial. Trop Doct. 2010 Jul; 40(3):144-8.

19. Wong KS, Ngai CS, Yeo EL, Tang LC, Ho PC. A comparison of two regimens of intravaginal misoprostol for termination of second trimester pregnancy: A randomized comparative trial. Hum Reprod. 2000 Mar; 15(3):709-12.

20. Niroomanesh S, Fesharaki H. Comparison of effectiveness of two vaginal Misoprostol regimens, $400 \mu \mathrm{g}$ and $600 \mu \mathrm{g}$, on pregnancy termination in the 2nd trimester. J Reprod Infertil. 2004; 5(2):150-7.

21. Bugalho A, Bique C, Almeida L, Fau'ndes A. The effectiveness of intravaginal misoprostol (Cytotec) in inducing abortion after eleven weeks of pregnancy. Stud Fam Plann. 1993; 24:319-23.

22. Yapar EG, Senoz S, Urkutur M, Batioglu S, Gokmen O. Second trimester pregnancy termination including fetal death: Comparison of five different methods. Eur J Obstet Gynecol Reprod Biol. 1996; 69:97-102.

23. Elsheikh A, Antsaklis A, Mesogitis S. Use of misoprostol for the termination of second trimester pregnancies. Arch Gynecol Obstet. 2001; 265:204-6. 


\title{
A whole generation worked to empower women, but forget to teach men how to live with empowered women.
}

\author{
“Unknown”
}

\begin{tabular}{|c|c|c|c|}
\hline \multicolumn{4}{|c|}{ AUTHORSHIP AND CONTRIBUTION DECLARATION } \\
\hline Sr. \# & Author(s) Full Name & Contribution to the paper & Author(s) Signature \\
\hline 1 & Shamas un Nisa & $\begin{array}{l}\text { Review of literature, Data } \\
\text { analysis, Study concept. }\end{array}$ & Forag Raver \\
\hline 3 & Sadaf un Nisa & Drafting, Proof reading. & Sadaf \\
\hline
\end{tabular}

